\title{
Echoes of Eriugena in the Old English Boethius
}

\author{
Eleni Ponirakis ${ }^{1} \mathbb{D}$
}

Accepted: 18 January 2021 / Published online: 23 February 2021

(C) The Author(s) 2021

\begin{abstract}
This article identifies a passage from Eriugena's Periphyseon as a source for an interpolation in the Old English Boethius. The interpolation introduces an unambiguous reference to the Neoplatonic idea of reditus, the return of all created creatures to God. This is not the first such evidence of Neoplatonic ideas in Old English texts and the article explores the significance of this new identification as further evidence for the presence of eastern mystical traditions in early English monastic and courtly circles, challenging the idea that English mysticism began in the Middle English period.
\end{abstract}

Keywords Old English · Neoplatonic · Old English Boethius · Eriugena · Theosis

\section{The Old English Boethius and the Periphyseon}

In a departure from the Latin original, the translator of the prose version of the Old English Boethius $(O E B)$ has added two sentences towards the end of chapter twentyfive which make a direct and overt reference to the Neoplatonic, and more specifically Eriugenian, philosophy of exitus and reditus, the idea that all things come from and return to God. This idea is one of the central propositions in John Scottus Eriugena's Periphyseon, and a very similar passage is to be found in book $\mathrm{V}$ of that work, the ultimate chapter of the Periphyseon centring on the philosophy of reditus. ${ }^{1}$

This is not the first echo of Eriugenian thinking to be identified in the Alfredian corpus; in 1993, Michael Treschow drew attention to parallels between Eriugena's Periphyseon and the Alfredian translation of Augustine's Soliloquies, where there was 'considerable correspondence in thought and detail' (Treschow 1993, p. 281). Daniel Anlezark also identifies evidence of Platonic philosophy and the question of reditus in the Alfredian translations of the Soliloquies (Anlezark 2017), while Jean Ritzke-Rutherford (1980) identifies evidence of the influence of Pseudo-Dionysius

\footnotetext{
${ }^{1}$ For an account of the development of Eriugena's philosophy of reditus, see Mainoldi (2020).

Eleni Ponirakis

eleni.ponirakis@nottingham.ac.uk

1 School of English, The University of Nottingham, Nottingham, UK
} 
through the work of Eriugena in both the Alfredian translations and even more clearly in the sermons of $Æ l f r i c .{ }^{2}$ This paper will compare the Old English interpolation in $O E B$ with the passage in Eriugena to demonstrate the similarities, before considering each passage in its wider context and considering the implications of the addition to our understanding of early English theology and mysticism.

It has been argued, by Dorothy Whitelock among others, that the additions in the Alfredian translations are merely copied or adapted from marginal commentaries to the Latin source manuscripts, although this has been questioned, most recently by Joseph Wittig (1983, pp. 157-98). ${ }^{3}$ There is a marginal commentary present in several manuscripts of the Latin source of the $O E B$ passage which has some correspondence with the interpolation. In order to understand the extent to which the interpolation identified in $O E B$ is significant, we must consider whether it merely repeats a marginal gloss or whether it reflects a deeper understanding of the source text and theologoumena therein. The more important question here is not, however, whether the translator was using the commentary, but whether the translator was knowingly espousing the Neoplatonic philosophies implied therein.

The passage in the $O E B$ (B-text, prose version) 25.28-31 reads as follows:

Nis nan gesceaft gesceapen ðara pe ne wilnige pæt hit pider cuman mæge ponan pe hit ær com, pæt is to ræste and to orsorgnesse. Seo ræst is mid Gode and pæt is God (Godden and Irvine 2009, I, hereafter OEB I, p. 294).

There is no created creature that does not desire to be able to return to where it came from before, that is to rest and to tranquillity. The rest is with God and it is God. ${ }^{4}$

This does not correspond to the Latin original of Boethius' De Consolatione Philosophiae $(D C P)$, but does pick up on Boethius' imagery. The Latin text gives numerous examples from nature of things continually seeking to return to their natural state, as a demonstration that it is man's nature to tend towards the good, even if he all too often mistakes what that good is, est enim mentibus hominum veri boni naturaliter inserta cupiditas, sed ad falsa devius error abducit (for the desire for the true good is naturally inborn in the minds of men, but they are led astray after false goods. DCP 3p2, 13-15; trans. S. J. Tester). In the Latin, however, there is no reference to an idea that all things return to God.

The relevant passage from the fifth and concluding book of Eriugena's Periphyseon reads:

\footnotetext{
${ }^{2}$ See also Flight (2017) and Leneghan (2016). Leneghan identifies evidence for the doctrine of theosis in the Old English poem The Wanderer. This is theosis linked to prayer, as distinct from the eschatological version of theosis implicit in reditus.

${ }^{3}$ Wittig cites Whitelock's assumption (1969) that the Old English translator was using marginal glosses close to those of Remigius of Auxerre. Remigius was taught by Heiric of Auxerre, a follower, and possibly a pupil of Eriugena. See also Hobson (2017).

${ }^{4}$ Translations are my own unless otherwise stated.
} 
Table 1 Comparison of $O E B$ and Periphyseon

\begin{tabular}{|c|c|}
\hline Old English Boethius & Periphyseon \\
\hline $\begin{array}{l}\text { 1. Nis nan gesceaft gesceapen ðara pe ne wilnige } \\
\text { pat hit pider cuman mage ponan pe hit ar com }\end{array}$ & $\begin{array}{l}\text { 1. Nulla corporea creatura est uitali motu uegetata, } \\
\text { quae non ad principium motus sui reuertatur }\end{array}$ \\
\hline $\begin{array}{l}\text { There is no created creature that does not desire to } \\
\text { be able to return to where it came from before }\end{array}$ & $\begin{array}{l}\text { There is no corporeal creature enlivened by the } \\
\text { Vital Motion which does not return again from the } \\
\text { beginning from which it set forth }\end{array}$ \\
\hline 2. & $\begin{array}{l}\text { 2. Finis enim totius motus est principium sui. Non } \\
\text { enim alio fine terminatur, nisi suo principio, a quo } \\
\text { incipit moueri, } \\
\text { For the end of every movement is in its beginning: } \\
\text { it is concluded in no other term but that origin out } \\
\text { of which its movement began }\end{array}$ \\
\hline $\begin{array}{l}\text { 3. Jara pe ne wilnige pat hit pider cuman mage } \\
\text { ponan pe hit ar com, paet is to raste and to } \\
\text { orsorgnesse }\end{array}$ & $\begin{array}{l}\text { 3. et ad quod redire semper appetit, ut in eo desinat } \\
\text { atque quiescat }\end{array}$ \\
\hline $\begin{array}{l}\text { [nothing] that does not desire to be able to return } \\
\text { to where it came from before, that is to rest and } \\
\text { to tranquillity }\end{array}$ & $\begin{array}{l}\text { and to which it ever seeks to return in order that it } \\
\text { may have peace and rest }\end{array}$ \\
\hline $\begin{array}{l}\text { 4. Seo rast is mid Gode and pat is God } \\
\text { The rest is with God and it is God }\end{array}$ & 4 \\
\hline
\end{tabular}

Ac simpliciter dicendum: Nulla corporea creatura est uitali motu uegetata, quae non ad principium motus sui reuertatur. Finis enim totius motus est principium sui. Non enim alio fine terminatur, nisi suo principio, a quo incipit moueri, et ad quod redire semper appetit, ut in eo desinat atque quiescat. (Jeauneau 2004, 866C).

In short, there is no corporeal creature enlivened by the Vital Motion which does not return again from the beginning from which it set forth. For the end of every movement is in its beginning: it is concluded in no other term but that origin out of which its movement began, and to which it ever seeks to return in order that it may have peace and rest. (O'Meara 1987, 866C).

If we number the corresponding phrases we can easily see the similarities and discrepancies between the two passages. Part of phrase 1. in $O E B$ corresponds with both phrases 1 . and 2. in the Periphyseon and so is repeated in the table below (Table 1).

The idea in both texts is the same. That is that all creatures created by God desire to return to God and to find rest and peace. This is reditus, a Neoplatonic concept which can be traced back to Plotinus' idea developed in the Enneads, that all things proceed from and return to the One and feel a longing to return (Carabine 1995, pp. 126-7). Plotinus was an early and lasting influence on St Augustine of Hippo, one of Eriugena's most frequently cited sources. However, in developing his own theory, 
Eriugena drew greatly on Pseudo-Dionysius, as well as Gregory of Nyssa and Maximus the Confessor (Carabine 2000, pp. 93-101). ${ }^{5}$

The idea is the same in both texts and there is a degree of correspondence of expression in the points which I have numbered 1. and 3., including the negative construction. The gesceaft gesceapen (created creature) of the Alfredian text corresponds to the corporea creatura ... uitali motu uegetata (corporeal creature enlivened by Vital Motion) in the Periphyseon. Eriugena defines Vital Motion as 'the nutritive life principle' which via Aristotelian metaphysics is God, 'the unmoved mover and first cause' (O'Meara 1987, 825D). ${ }^{6}$ OEB implies the hand of God in the repeated reference to creation, gesceaft and gesceapen. Both texts express the desire of the created creature to return to the creator, which, as we have seen, is a Plotinian concept. Plotinus, not a Christian, saw this in terms of a desire to return to the Good, and this desire to return to good is one that is present in $D C P 3 \mathrm{p} 2$, the prose chapter immediately preceding $3 \mathrm{~m} 2$ into which our Alfredian text has been interpolated. Boethius himself refers to Epicurus' failed search for the highest good, adding:

sed ad hominum studia revertor, quoram animus etsi caligante memoria tamen bonum suum repetit,

but I turn back to the endeavours of men: for man's mind, though the memory of it is clouded, yet does seek again its proper good.

(DCP 3p2, 51-3; trans. S. J. Tester).

Finally, both texts refer to the result of reditus being a cessation of movement and a finding of peace, the nouns rast and orsorgness in the Old English, 'rest / stillness' and 'tranquillity', convey the same idea as the verbal forms desino and quiesco in the Latin, 'to cease' and 'to be at peace'.

The differences between the two passages are perhaps as interesting as the similarities. The phrase from the Periphyseon that I have labelled 2. in the table, and which has no correspondence in the interpolation, corresponds quite closely to the Latin passage in DCP. The circular image in finis enim totius motus est principium sui. Non enim alio fine terminatur, nisi suo principio, a quo incipit moueri, 'for the end of every movement is in its beginning: it is concluded in no other term but that origin out of which its movement began', is closer to the Latin of DCP closing the metre:

Repetunt proprios quaeque recursus.

Redituque suo singula gaudent.

Nec manet ulli traditus ordo.

Nisi quod fini iunxerit ortum.

Stabilemque sui fecerit orbem.

Each thing seeks its own way back.

\footnotetext{
${ }^{5}$ Russell traces the influence of Dionysius' teaching of 'the unification of the whole Christian order with God through a movement of return effected by a process of purification, illumination, and perfection' to Proclus and Origen, Russell (2004, p. 246). Some scholars include Gregory of Nazianzus as an influence, but Eriugena was under the misapprehension that Gregory of Nazianzus (also known as the Theologian) and Gregory of Nyssa were one and the same person; see Jeauneau (1983, pp. 141-2).

6 The idea of motus originates in Aristotelian metaphysics where God is the "unmoved mover and first cause'; see Russell (2004, p. 36).
} 
And coming back is glad;

None is consigned to any ordered course.

Save that which links the end to the beginning.

And makes its circle firm. (DCP 3m2, 34-8; trans. S. J. Tester).

The Alfredian rendition of this metre would seem to be the phrases surrounding the interpolation,

swa deð ælc gesceaft, wrigað wið his gecyndes and gefagen bið gif hit æfre to cuman mæg. [...] Ac ælc gesceaft hwearfað on hire selfre swa swa hweol and to pam heo swa hwearfað pæt heo eft cume pær heo ær wæs and beo pæt ilce pæt heo ær wæs, ðonecan ðe heo utan behwerfed sie [pær pær] hio ær wæs, and do pæt pæt heo ær dyde [...] (OEB I, p. 294).

so does each creature, [it] turns towards its own nature and is happy if it may ever come there. [...] But each creature turns on itself like a wheel and turns so that it may come after to where it was before and may be the same as it was before, as soon as ever it is turned around to where it was before, and may do what it did before.

The circular image of creatures returning to their starting point is present in both, although the Alfredian version makes it clear that this is more than a spatial return, but a return to an original nature or way of being. ${ }^{7}$ Whilst it renders the Boethian original it is closer to the Eriugenian version which references an 'origin'. As the idea is already stated, however, it did not need to be repeated in the direct interpolation from the Periphyseon; this implies that the interpolation is very much a synthesis of both DCP and the Periphyseon. The Old English text adds the precision that the rest and tranquillity found in the return is God Himself. Although not in this particular passage from the Periphyseon, the central argument of book five is that all creatures return to God. The addition in the Alfredian text serves to clarify that the argument present in this interpolation is specifically that of reditus, the return of all created things to the creator who made them.

An important element of Eriugena's idea of reditus expressed in the Alfredian interpolation is that of epektasis, that is the theory that all rational creatures eternally seek God; it is an eternal striving of the soul towards God. ${ }^{8}$ Eriugena appears to have adopted this idea from Gregory of Nyssa. In both the Alfredian interpolation and the corresponding passage from the Periphyseon, this desire is expressed negatively, that there is no creature that does not desire to return to its origins to find peace and rest. ${ }^{9}$

\footnotetext{
7 The Alfredian translator also uses the image of a wagon wheel to describe eall yios unstille gesceaft and peos hwearfiende (OEB I, p. 363, all this unstill and turning creation) which hwearfoð on pam stillan Gode and on pam gestcððegan and on pam anfealdan (turns around the still and stable and single God) like the rim and spokes of the wheel. This is to demonstrate that the closer one is to God, the less one is moved by emotions and worldly cares.

8 For a full explanation of epektasis, see Petcu (2017, pp. 771-82).

9 It is possible that the use of a negative construction is a nod to apophasis. Carabine defines this theory,

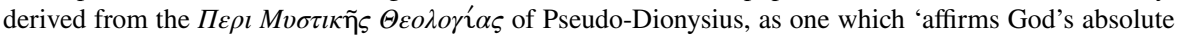
transcendence and unknowability to such an extent that no affirmative concepts, except that of existence, may be applied to him' (Carabine 1995, p. 2).
} 
It seems significant that the Alfredian translator has chosen to insert a passage which offers an unambiguous reference to reditus, a form of theosis. ${ }^{10}$ Before drawing any conclusions, however, it will be important to consider the marginal gloss from the Latin which seems to correspond to this interpolation.

\section{The Gloss: An Alternative Source?}

Godden and Irvine identify a marginal comment present in a number of the manuscript exempla of $D C P$, both in England and on the continent which also refers to the circular end-point being with God: finis et ortus est deus. in quo incipimur et resoluimur (OEB II, p. 343). The commentaries and departures often seek to make DCP more overtly Christian, Boethius making few direct references to Christianity. ${ }^{11}$ However, depending on how this comment is translated it can be seen to be alluding to more than just a reminder of the importance of God. The Boethian metre, $3 \mathrm{~m} 2$, most of which is quite faithfully rendered in the Old English prose, gives a series of examples to demonstrate how all things in nature return to their origins. There is a tame lion returning to its savage state, a wild bird in a cage yearns to return to the woods and the bough of a tree bent to the ground will return to its position on release. The Latin commentary seems to be picking up on the images of captivity and release suggested by the tame lion and the caged bird with the verbs incipio (to take hold, take in hand, begin...) and resolvo (to untie, unfasten, unbind, loose, loosen, release, open), and the passage can be translated 'the end and the beginning is God in whom we are being both taken in hand and released'. ${ }^{12}$ However, if we apply a specifically Eriugenian value for resolvo, we can translate this as, 'the end and the beginning is God (in)to whom we are being both begun and returned / resolved'. This version is an expression of reditus. 'Return' is not a common value for resolvo in medieval Latin, but it is a typically Eriugenian use of the term. In the Periphyseon, Eriugena uses resolvo to gloss the Greek term, $\alpha \nu \alpha \lambda$ ó $\omega$ (to analyse), and explains why in some detail,

N. ANA $\Lambda \Upsilon T I K H$ a uerbo $\operatorname{ANA} \Lambda \Upsilon \Omega$ deriuatur, id est resoluo uel redeo; ANA enim re, $\Lambda \Upsilon \Omega$ uero soluo interpretatur. Inde etiam nomen nascitur ANA $\Lambda$ YCIC, quod in resolutionem uel reditum similiter uertitur [...] Est igitur reditus et resolutio indiuiduorum in formas, formarum in genera, generum

\footnotetext{
${ }^{10}$ Theosis is a Greek term first used by Clement of Alexandria and defined by Pseudo-Dionysius as 'the attaining of likeness to God and union with him so far as is possible' (Russell 2004). There are two main forms of theosis, one is a union with God through prayer, and the other is a return to God after death (reditus). Theosis was considered to belong almost exclusively to Eastern theology until recently, but this idea is being challenged by modern theologians. See Nelstrop (2020).

11 The Old English replaces Natura with Drihten, 'the Lord', and mirroring the West Frankish interpretation replaces Philosophia with Wisdom, "for the "anonymous of St Gallen” and Remegius, Philosophia represented not only divine Sapientia, but Christ himself, whom Paul had identified as the wisdom of God', Pratt (2017, p. 275).

12 Perseus Digital Library, https://www.perseus.tufts.edu/hopper accessed 23 August 2020.
} 
in OYCIAC, OYCIArum (sic) in sapientiam et prudentiam, ex quibus omnis diuisio oritur in easque finitur. (Eriugena 2004, 526B).

N.'A $\nu \alpha \lambda v \tau \tau$ เ return"; for $\alpha \nu \alpha$ - stands for "re-", $\lambda \hat{v} \omega$ for "solve". Thence comes also the noun

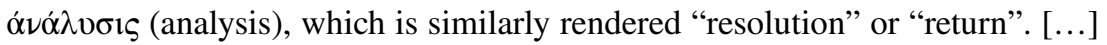
Thus it is the return and resolution of individuals into forms, of forms into

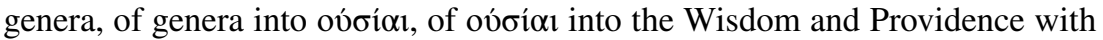
which every division begins and in which every division ends. (O'Meara 1987, 526B). ${ }^{13}$

An early medieval reader of Latin in England would probably not have understood the use of resolvo in the commentary as having a value of 'resolution' or 'return', without being familiar himself with the work of Eriugena. So, if this was the prompt for the interpolation it implies an in-depth knowledge of both the ideas and the semantic range of Eriugena in both the continental commentator and the English translator.

If we translate the commentary as 'the end and the beginning is God (in)to whom we are being both begun and returned / resolved', it corresponds to both phrase 2 . and phrase 4. in the table. It seems clear that the glossed comment is linked to the Alfredian interpolation, but does not account for the correspondence linking phrases 1. and 3. in $O E B$ to corresponding phrases in the passage from the Periphyseon. ${ }^{14}$ Rather it suggests that the English translator has recognised the reference to reditus in the commentary and been prompted to add in a fuller quotation adapted from the Periphyseon itself. Both the Latin glossator and the English translator have recognised the aptness of this passage in Boethius as an exemplum of the arguments made by Eriugena in the Periphyson and this is quite likely because the larger context of the chapter in which this passage is to be found uses similar examples, as we will see. If this is the case, it also suggests that both the Carolingian glossator and the Alfredian translator were familiar with and espoused the Neoplatonic philosophy of the Eriugenian text. ${ }^{15}$

\footnotetext{
${ }^{13}$ Eriugena uses the unusual present indicative passive form resolvimur to gloss the Greek form $\dot{\alpha} \nu \alpha \lambda v \theta \tilde{\eta} \nu \alpha l$ in his own translation of Maximus the Confessor from the Ambigua where he quotes the

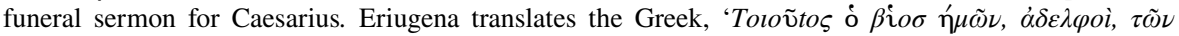

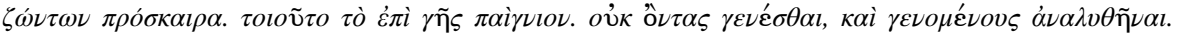

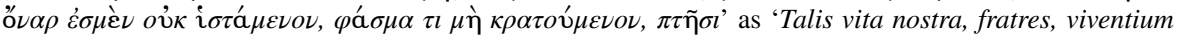
ad tempus, qualis in terra ludus. Non existentes efficimur et facti resolvimur, somnium sumus instabile, volatus avis transeuntis adhuc eo longius' (Lehman 1917, pp. 112-24). Louth (1996, p. 166) translates the Greek as, 'Such is our life, brothers, the passing life of living beings: a sort of play upon the earth. As those that have not been, we come into being, and having come into being we are dissolved. We are a dream that does not last, a passing phantom, the flight of a bird that is gone'.

${ }^{14}$ It is possible that an, as yet, unidentified commentary exists which contains more of the Eriugenian passage, but even this would not rule out the Alfredian translator's understanding and espousing of the allusion.

${ }^{15}$ For more about the nature of the commentaries to $D C P$, including the question of whether some of them were by Eriugena himself, or by Remigius of Auxerre who was heavily influenced by Eriugena, see Love (2014).
} 
The Periphyseon takes the form of a debate between a master, Nutritor, and a student Alumnus. In book V, Nutritor explains to his student, the idea of reditus. He begins:

sed priusquam de ipso reditu nostrae naturae tractemus, quaedam ex sensibilibus probatissima argumenta, quibis docemur incunctanter credere ipsum futurum esse, sumenda existimo, si tibi uidetur (Jeauneau 2004, 865C).

but before we treat of the Return of our nature, I should like, if you agree, to draw from the sensible world some very convincing evidence which sets the Return beyond all doubt (O’Meara 1987, 865C).

Just as Philosophy (Wisdom in the Old English) in $3 \mathrm{~m} 2$ gives examples of things in nature seeking to return to their origins, the lion, the bird, the branch and the sun, Nutritor also gives examples. Eriugena begins with the stars, sun and moon, moves on to the air, the Ocean and the tides and finishes with 'the creatures of sea and land, the grasses and twigs'. Anyone familiar with the Periphyseon would be struck by the familiarity of examples from nature to demonstrate that all things seek to return to their original nature that is used in both Boethius and Eriugena. Although Boethius does not directly express an idea of a return to God as a universal principle here, the idea of all things returning to their beginnings is used by Boethius to demonstrate man's desire and yearning towards good, and that good can only be God.

This paper has shown that the interpolation towards the end of chapter twentyfive in $O E B$ is taken from Eriugena's Periphyseon and is an expression of the Neoplatonic idea of reditus, a form of theosis. It has further demonstrated that the interpolation is linked to a marginal commentary present in several of the Latin manuscripts of $D C P$, which is itself a reference to reditus expressed in specifically Eriugenian terms. As the interpolation gives a fuller version of the equivalent passage in the Periphyseon than is present in the commentary, it seems clear that the translator was aware of Eriugena's work, was able to see the strong correspondences between the two texts, DCP and Periphyseon, and had a clear enough understanding and espousal of the Neoplatonic idea of reditus implicit therein to make a synthesis of the two. This paper adds to the growing body of evidence that demonstrates the awareness and even integration of Neoplatonic ideas in England before the conquest, demonstrating a need for a reappraisal of our understanding both of Old English texts, and of early English theology.

\section{Availability of data and material}

Not applicable.

Acknowledgements I would like to thank Francis Leneghan, Susan Irvine, Paul Cavill and Colleen Curran for their helpful comments.

Author contributions Not applicable.

Funding Not applicable. 
Code availability Not applicable.

\section{Compliance with ethical standards}

Conflict of interest The authors declare that they have no conflict of interest.

Open Access This article is licensed under a Creative Commons Attribution 4.0 International License, which permits use, sharing, adaptation, distribution and reproduction in any medium or format, as long as you give appropriate credit to the original author(s) and the source, provide a link to the Creative Commons licence, and indicate if changes were made. The images or other third party material in this article are included in the article's Creative Commons licence, unless indicated otherwise in a credit line to the material. If material is not included in the article's Creative Commons licence and your intended use is not permitted by statutory regulation or exceeds the permitted use, you will need to obtain permission directly from the copyright holder. To view a copy of this licence, visit http://creativecommons.org/licen ses/by/4.0/.

\section{References}

Anlezark, D. (2017). The soul in the Old English Soliloquies and ninth-century neoplatonism. In A. Ahlqvist \& P. O’Neill (Eds.), Germano-Celtica: A festschrift for Brian Taylor (pp. 35-60). Sydney: Sydney Series in Celtic Studies. The University of Sydney.

Carabine, D. (1995). The unknown god-Negative theology in the platonic tradition: Plato to Eriugena. Eugene, OR: Wipf and Stock.

Carabine, D. (2000). John Scottus Eriugena. New York and Oxford: Oxford University Press.

Flight, T. (2017). Through a glass darkly: Evidence for knowledge of Pseudo-Dionysius in Anglo-Saxon England. Journal of Medieval Religious Cultures, 43, 1-23.

Godden, M., \& Irvine, S. (Eds. and Trans.). (2009). The Old English Boethius: An edition of the Old English versions of Boethius' 'De consolatione philosophiae'. 2 vols. Oxford: Oxford University Press.

Hobson, J. (2017). Translation as gloss in the Old English Boethius. Medium Evum, 86, 207-223.

Jeauneau, E. A. (Ed.). (2004). Iohannis Scotti seu Eriugenae: Periphyseon. Volumes 1-5. Corpus Christianorum Continuatio Medievalis. Turnholt: Brepols.

Jeauneau, E. (1983). Pseudo-Dionysius, Gregory of Nyssa, and Maximus the Confessor in the works of John Scottus Eriugena. In U.-R. Blumenthal (Ed.), Carolingian essays (pp. 137-149). Washington: Catholic University of America Press.

Krapp, G. P., \& Van Kirk Dobbie, E. (Eds.). (1936). The Exeter Book. ASPR III. New York: Routledge.

Lehman, P. (1917). Zur Kenntnis und Geschichte einiger Johannes Scottus zugeschriebener Werke. Hermes, 52, 112-124.

Leneghan, F. (2016). Preparing the mind for prayer: The Wanderer, hesychasm and theosis. Neophilologus, 100, 121-142.

Louth, A. (1996). Maximus the Confessor. London: Routledge.

Love, R. (2014). The Latin commentaries on Boethius' De consolatione philosophiae from the 9th to the 11th centuries. In N. H. Kaylor Jr. \& P. E. Phillips (Eds.), A companion to Boethius in the Middle Ages (pp. 82-110). Boston: Brill.

Mainoldi, E. S. (2020). The reception of the Greek patristic doctrine of deification in the medieval West: The case of John Scottus Eriugena. In J. Arblaster \& R. Faesen (Eds.), Mystical doctrines of deification: Case studies in the Christian tradition (pp. 60-71). London and New York: Routledge.

Nelstrop, L. (2020). On deification and sacred eloquence. London: Routledge.

O'Meara, J. (Ed. and Trans.). (1987). Eriugena: Periphyseon. Montreal and Washington: Dumbarton Oaks.

Perseus Digital Library. Retrieved Aug 23, 2020, from https://www.perseus.tufts.edu/hopper.

Petcu, L. (2017). The doctrine of Epektasis. One of the major contributions of Saint Gregory of Nyssa to the history of thinking. Revista Portuguesa de Filosofia, 73, 771-782.

Pratt, D. (2017). The political thought of King Alfred the Great. Cambridge: Cambridge University Press.

Ritzke-Rutherford, J. (1980). Anglo-Saxon antecedents of the Middle English mystics. In M. Glasscoe (Ed.), The medieval mystical tradition in England (pp. 216-233). Exeter: University of Exeter Press. 
Russell, N. (2004). The doctrine of deification in the Greek patristic tradition. Oxford: Oxford University Press.

Tester, S. J. (Trans.). (1973). Boethius: The consolation of philosophy. In H. F. Stewart, E. K. Rand and S. J. Tester (Eds. and Trans.), Boethius: Theological tractates. The consolation of philosophy (pp. 130-435). Cambridge, MA: Harvard University Press.

Treschow, M. (1993). Echoes of the Periphyseon in the third book of Alfred's Soliloquies. Notes and Queries, 40, 281-286.

Whitelock, D. (1969). William of Malmesbury on the works of King Alfred. In D. A. Pearsall \& R. A. Waldron (Eds.), Medieval literature and civilisation. Studies in memory of G. N. Garmonsway (pp. 78-93). London: The Athlone Press.

Wittig, J. S. (1983). King Alfred's Boethius and its Latin sources: A reconsideration. ASE, 11, 157-198.

Publisher's Note Springer Nature remains neutral with regard to jurisdictional claims in published maps and institutional affiliations. 